\title{
Representation of Ecological Contents in Mathematics Textbooks
}

\author{
Dragica Milinković \\ University of East Sarajevo \\ dragica.milinkovic@pfb.ues.rs.ba \\ Milenko Ćurčić \\ University of East Sarajevo \\ milenko.curcic@pfb.ues.rs.ba
}

\section{Slađana Mitrović \\ University of East Sarajevo \\ sladjana.mitrovic@pfb.ues.rs.ba}

Ecological education is an integral part of modern general education and in that sense it makes an inevitable component in the planning and programming of the teaching process. As an interdisciplinary principle, ecological education finds its place in various educational programmes, but in our schools it is mainly present in the teaching of integrated natural sciences. Having in mind the necessity of mathematical knowledge for understanding phenomena and laws in nature and society, when it comes to lower grades, students also get to know the phenomena and problems of ecology in real-life situations in mathematics classes. Ecological activities 'run' through textbook contents, mathematical stories and tasks with ecological messages, as well as models of approaches to mathematical problem solving, for example, the collection and analysis of mathematical data on water, soil and air pollution, the size of green areas in the city, the amount of garbage, etc. Practical activities that can relate to creating an eco-corner in which students will make accurate recycledmaterial mathematical solutions of a certain environment are of special importance. The analysis of the contents reveals the results that show that mathematics textbooks encourage ecological education and conscience. However, nowadays, when this type of education is considered an explicit task, it is not a sufficient contribution to maximizing ecological awareness in students.

Keywords: ecological education, interdisciplinary principle, mathematics, textbooks

\section{Introduction}

In recent decades, ecology and environmental protection have flourished, and environmental education has become an integral part of modern general education. The most important goal of environmental education is cer- 
tainly to form students' awareness of problems and environmental pollution, but also ecologically conscious behaviour, which should be maintained after school.

According to Đorđević and Cvetković (2014), ecology has become a synthesis of all scientific disciplines that study humans and the living world, a synthesis of knowledge and facts at the centre of which are humans and the organization of life on Earth.

Ecology studies the disposition and distribution of living organisms and biological interactions between organisms and their environment (Žderić 1983), the flow of energy and the circulation of matter in nature: earth, water and air. Ecology is a branch of biology, and due to its specific needs, it unites numerous scientific disciplines and their methods: botany, zoology, anthropology, pedology, geology, meteorology, hydrology, mathematics, physics, chemistry and others (Đikić et al. 2001).

Ecology, as an exact biological discipline, has found its place in other natural sciences studied in primary school and, accordingly, environmental education has become an indispensable component in the planning and programming of the teaching process. The interdisciplinarity of ecology with subjects in primary school is reflected in its strong links with the teaching contents of biology, geography, nature and society, mathematics, chemistry, physics, etc. (Skenderović and Romelić 2013).

As the younger school age is a very important period for understanding the phenomena and laws in nature that are necessary for the development of an ecological conscience, in today's conditions, environmental education is represented in the teaching of the basic school cycle, represented within integrated and 'separate' subjects and interdisciplinary topics (Jukić 2011).

Considering that in the younger grades of primary school, ecological contents are predominantly represented in the subject Nature and Society (Priroda i društvo), and that they 'run' through mathematical contents, we will point out the interdisciplinary connections between mathematics and nature and society when processing teaching units related to ecological contents. In this process, students will rely on previously acquired knowledge in mathematics and ecology, assimilate new knowledge and further develop it by solving problems in both mathematics and ecology (Blagdanić and Zeljić 2016). The textbook as the most represented medium will have a guiding role in that process, on the quality of which the quality of students' ecological knowledge will significantly depend. Robitaille and Travers (1992) explain the great influence of textbooks by the contents and the ways in which they are didactically-methodically shaped. 


\section{Theoretical Approach}

Environmental education must be an imperative at all levels of education, especially primary education, where we must educate students in good and healthy habits from an early age. Environmental education should be a lifelong process. It should include the curriculum from kindergarten age, because then children accept this type of subject very well. The knowledge acquired in one class should be upgraded and expanded in the next. It is extremely important that the curriculum connects subjects related to education in the human environment, both in the natural and social sciences. Thus, the overall knowledge will be properly developed for the purpose of solving and understanding environmental problems. Also, it is necessary for the programme to enable students to learn in natural conditions (Skenderović and Fetić 2014).

Ecological awareness must be emphasized as much as possible because the time in which we live is full of many negative tendencies in all spheres of life. Ecological contents in the textbooks of natural sciences in the Republic of Srpska, Nature and Society and Mathematics, are well designed, and sufficiently represented by grades, i.e. the age structure of students. It is very important that primary school teachers understand that nature cannot be replaced by a classroom or a textbook. Obviousness must be represented as a key didactic principle in the natural sciences. By frequent trips in nature, we awaken students' imagination, their senses, interests, teach them a healthier way of life, influence their psychosocial development, and especially improve their ecological culture.

Ecology is, in short, a science that deals with the study of the relationship between living beings and their environment. Humans, plants and animals are in constant interdependence with each other, in special synergistic relationships important for their reproduction, nutrition, and survival. Their activities in the habitats they inhabit significantly affect the overall environment or, better said, all ecosystems - terrestrial, aquatic and air. Through the teaching of Nature and Society, ecological contents are especially emphasized, which refer to the protection of these ecosystems, their revitalization and ways of faster recovery from uncontrolled exploitation, degradation or use of illegal quantities of herbicides, pesticides, fertilizers and other illegal chemical agents. Our waters are polluted - rivers, ponds, lakes, seas. The land is polluted, so is the air. All this endangers the life and survival of a large number of plant and animal species that live in these ecosystems. As Skenderović and Fetić (2014) state, 'knowledge about pollution and ways to reduce or 
avoid pollution are the subject of environmental education.' We have to point out to the students all the negative influences that mostly come from people, so we have to educate them as well as possible for the time ahead of them, that is, for their better tomorrow. After this education, students will be able to adopt and apply the principles of ecological thinking and behaviour, as well as to act in accordance with them.

The teaching of Nature and Society in the classroom must contribute to the intellectual and social-emotional development of students so that they can design all activities for the preservation and protection of the environment in a timely manner.

If primary school teachers are sufficiently dedicated and inventive, they can find various ways to motivate students and initiate various activities that can be used to protect the environment. For that purpose, modern teaching aids, the internet and social networks can be used, which are now the everyday life of almost all students. Teachers are an extremely important factor in the realization of the goals of environmental education.

However, mathematics is crucial for the development of critical and abstract thinking, logical-deductive reasoning, and understanding the laws of nature, which we can assume are necessary for the development of ecological consciousness (Eulefeld 1981).

Nature and Society as a subject must unite the contents of different scientific fields, natural and social (chemistry, physics, mathematics, biology, geography, history, mother tongue, informatics, etc.). Students should master the key concepts that allow upgrading the content of natural and social subjects in the upper grades of primary school.

We must educate students to experience nature as a small classroom where all living things have the same basic needs for survival, food, habitat, sun, oxygen and water. With the youngest ones, through schools in nature, trips, devising games where they will play plants and animals in the given weather conditions and take care of their protection and nutrition. With the older students, through organizing field classes in certain living communities (meadows, orchards, forests, ponds, etc.) where students will see the interdependence of plant and animal organisms in numerous food chains.

Every day we notice, all around us, that the relationships between living beings and the environment in which they live are increasingly disrupted. Modern technology and the modern way of life are the main culprits for such a state of nature. We live in an environment that is pretty much destroyed. Many generations from the previous century (XX) caused great damage to planet Earth and thus put the survival of humanity in a very difficult situation. 
Together we need to provide a healthier and better quality of life for future generations, not only of humans but also of plants and animals. We need to provide more drinking water, healthy food and clean air (Ćurčić 2018).

With insufficient attention, carelessness, and often out of ignorance, man endangers the environment: land, water and air. In that way, he endangers his health and makes his life less pleasant. That is why people agree on what their obligations are to protect the environment and how those obligations will be fulfilled. All citizens should take care of the protection of the environment, especially the workers and associations of citizens in charge of that. (Pašalić, Radivojević, and Stanojlović 2019)

Land is an important condition for the life of plants and animals. However, some people do not protect it and pollute it. Soil pollution is mostly affected by improper disposal of garbage, wastewater from factories, city sewers, improper use of artificial fertilizers and improper protection of plants from pests. Soil pollution reduces the production of healthy food for animals and humans. This endangers the lives of humans and animals (Ćurčić et al. 2018).

\section{Research Method}

The aim of the research was to determine the frequency of tasks in mathematics textbooks in the classroom from the aspect of contribution to environmental education and upbringing.

The research was performed on a sample of the First Book for the first grade of primary school and mathematics textbooks for the second, third, fourth and fifth grade, which were approved for publication and use by the Ministry of Education and Culture of the Republic of Srpska for the school year $2020 / 2021$. As only one textbook publisher is represented in the Republic of Srpska, they are used in all schools.

A descriptive method was used for the realization of the research, with content analysis as a research technique. As a unit for the analysis of textbooks in mathematics, the task was determined, considering that the teaching contents of the subject of mathematics in the younger grades of primary school are mostly conceived through tasks (Pikula and Milinković 2015). 'By task, we meant each individual request set in a certain form (expression, equality, text, illustration, etc.) that is set before the student' (Maričić and Špijunović 2014, 534). At the level of identifying and grouping data, content analysis involved the process of classifying tasks from mathematics textbooks into categories determined from the aspect of contribution to environmental education and upbringing. 


\begin{tabular}{r|r|r|r|} 
Other tasks & & 95.95 \\
'Environmental' tasks & 4.05 &
\end{tabular}

Figure 1 Representation of 'Environmental' Tasks in Mathematics Textbooks

Content units for analysis, that is, tasks, are grouped into categories determined according to the potential of developing awareness of the basic characteristics of the human environment, the relationship in it and the relationship to it:

- 'environmental' (that contribute to environmental education and upbringing);

- 'non-environmental' (which do not contribute to environmental education and upbringing).

Statistical processing of data, based on the previously described method of their grouping, was performed at the level of frequencies and percentage of categories.

\section{Research Results}

By analysing the content of the First book for the 1st grade of primary school, related to mathematical content, and mathematics textbooks for the second, third, fourth and fifth grade, we singled out tasks that encourage environmental education ('environmental' tasks). We identified a total of 2668 tasks of which 2560 , or $95.95 \%$, do not encourage environmental education, and only 108 , or $4.05 \%$, provide a greater or lesser contribution to the development of students' ecological conscience, which is almost negligible (see figure 1).

Analysis of the frequencies and percentage of 'environmental' tasks in textbooks by grade, indicates the least 'environmental' tasks in the fifth (20, or $2.48 \%)$, and most in the first grade $(21$, or $22.83 \%$ ) (see table 1). There are 21 of them in the second grade textbook (4.37\%), 21 in the third (3.50\%), and 25 in the fourth $(3.62 \%)$ in relation to the total number of mathematical tasks, although it was expected that the number of tasks that enable development increase ecological conscience in proportion to the age of students, that is, by grades. The reasons for such a small number of tasks that function as environmental education should be sought in the fact that in younger grades mathematics teaching is limited to mastering mathematical skills, while contextual tasks are primarily intended for gifted students who are referred to additional textbooks, primarily collections whose contents are more diverse. 
Table 1 Representation of 'Environmental' Tasks in Mathematics Textbooks (by Grades)

\begin{tabular}{|c|c|c|c|c|c|c|}
\hline \multirow[t]{2}{*}{ Grade } & \multicolumn{2}{|c|}{ 'Environmental' tasks } & \multicolumn{2}{|c|}{ Other tasks } & \multicolumn{2}{|c|}{ Total } \\
\hline & $f$ & $\%$ & $f$ & $\%$ & $f$ & $\%$ \\
\hline 1st & 21 & 22.83 & 71 & 77.17 & 92 & 100.00 \\
\hline 2nd & 21 & 4.37 & 459 & 95.63 & 480 & 100.00 \\
\hline $3 r d$ & 21 & 3.50 & 579 & 96.50 & 600 & 100.00 \\
\hline 4 th & 25 & 3.62 & 665 & 96.38 & 690 & 100.00 \\
\hline 5th & 20 & 2.48 & 786 & 97.52 & 806 & 100.00 \\
\hline Total & 108 & 4.05 & 2560 & 95.95 & 2668 & 100.00 \\
\hline
\end{tabular}

\section{Discussion}

The results of our research have shown that ecological contents are not sufficiently represented, that is, incorporated in mathematics textbooks in the younger grades of primary school. The lack of ecological content can certainly be attributed to the authors of textbooks who insufficiently or completely superficially 'insert ecology' into mathematical tasks. It is symptomatic that less and less ecological content is represented in the third, fourth and fifth grade, and more in the first and second. It would be more logical if it were the other way around, considering the age of the students. Regardless of all these data that we arrived at in our research, we will point out all that is good and positive in the interpretation of environmental content, but also some content that should be incorporated in future editions of mathematics textbooks for younger grades of primary school.

One of the biggest environmental problems today is the pollution of the soil that 'feeds' humankind because all the plant world is tied to the earth. Every day, the country is increasingly endangered by numerous landfills of various types of garbage that contaminate the country with numerous highly toxic substances.

Given the time in which we live and all the weight that burdens a person every day, and for which the biggest culprit is modern technology and modernization, especially in urban areas, the biggest problem is where to dispose of huge amounts of garbage. This is where the sources of infection begin if it is not done in a safe way. There is little environmental content in math textbook assignments related to selective garbage disposal, especially in urban areas where most utilities are inconsistent in meeting garbage disposal criteria, which endangers human health. In addition, there are few populated places in the Republic of Srpska that have criteria for selective garbage disposal (paper, glass, food, plastic, etc.) because the ecological culture of our 
people is still at a low level. It is commendable that mathematics textbooks present tasks whose contents are related to medicinal plants, and partly to their importance for human health.

When it comes to content related to weeds that cause allergic reactions in humans, it is evident that they are not presented through assignments in math textbooks, although allergies are a serious environmental problem because more and more adults and children are allergic to pollen, not only weed plants, but also some woody plants (deciduous and coniferous), and plants that make up grassy areas.

We consider that teachers on their own initiative on field trips or schools in nature need to show students allergenic plants, especially ragweed, which causes the most common allergic reactions in most people, and to 'create' mathematical problems with that problem.

Also, the appearance of illegal landfills where huge amounts of garbage are dumped and which are a potential source of infection, is not presented to students through mathematical tasks, although it represents a very serious environmental problem.

We are still tied to cars which are the biggest air pollutants in populated areas. Their number is increasing day by day. The amount of harmful gases in the atmosphere is increasing, but also the number of sick people, even those with the most severe malignant diseases. On the other hand, there are very few bike paths so that people can use bikes more as a means of transportation. Problem-based tasks related to this topic are not represented in mathematics textbooks for the younger grades of primary school.

When it comes to contents related to soil pollution, i.e. its contamination with huge amounts of harmful substances, such as herbicides, pesticides, artificial fertilizers, etc., it is evident that they are not represented in mathematics textbooks, despite their adverse impact on the life and health of plants and animals that inhabit certain ecosystems, and thus on the health of humans who feed on them. This is certainly one of the biggest problems of today's civilization in which modern technology is taking its toll. One must strive to replace the energy sources used in the production of electricity, such as coal, oil, and gas, with solar energy. In that way, it will reduce the pollution of the land, water and air.

Modern humans must focus on ecological (biological) thinking. One of the biggest environmental problems is climate change, which directly affects the circulation of matter and energy in nature, and especially the circulation of water as an essential substance for the life of all organisms in the biosphere. Humans must also be visionary, and in that sense think mathematically. There 
is a science in the world today called mathematical biology. That is why mathematical contents are incorporated into the subject of nature and society, which additionally motivates students for an interdisciplinary approach in solving certain tasks related to natural sciences.

Mathematics is one of the basic subjects in primary school. There is no doubt that the value of mathematics in the formation of personality, development of intellect, logical thinking, development of creative abilities in solving problems (Milinković 2016), development of work habits and accuracy in work, is indisputable.

Mathematical knowledge is always needed to understand the laws and phenomena in nature, technology and society. Ecological awareness extends through textbook material, i.e. through models of approaches to solving a certain mathematical problem and the structure of mathematical tasks.

The idea of the problem of mathematical stories and the purpose of the types of tasks very much depends on the creativity of the teacher. Models of ecological messages through the teaching of mathematics can be used in the design of worksheets, quizzes and competitions in the school area. Forms of activities within the teaching of mathematics with an ecological message can be composed through textual tasks, as follows:

1. There are three birds on one branch of the beech, and two birds on the other branch below it. How many birds are there on the beach?

2. Sandra bought $11 \mathrm{~kg}$ of onions. For a mixed salad, which she prepares for the winter, according to the recipe, she needs $2 \mathrm{~kg}$ and $500 \mathrm{~g}$ of onions. To measure that amount, she has a scale with 2 bowls, two weights of $100 \mathrm{~g}$ and one weight of $50 \mathrm{~g}$. Explain how Sandra will measure $2 \mathrm{~kg}$ and $500 \mathrm{~g}$ of onions in three steps (Milinković 2013)?

3. Late in the autumn, Sasha and Masha observe an apple tree exposed to a strong wind. They observe the decline of apples and look at the clock, they state that for the first twenty minutes of observation, the same number of apples decreases every four minutes, and for the next twenty minutes, twice as many apples fall every four minutes. In the last third of the hour, a total of 5 apples fell. When they collected the apples, they found that there were a total of 95 apples. How many apples fell in the first four minutes (Pikula and Milinković 2015)?

Collection and analysis of mathematical data in the field of ecology, such as collecting data on weekly and monthly volumes of garbage and interpretation of the collected data, or calculating the area of green lawns around 
the school, or the number of seedlings of herbaceous, woody, ornamental and coniferous plants can be presented to students through mathematical stories with ecological content and account, especially those related to the wildlife of the forest and the fruits they use in their diet.

The connection of mathematics with nature and society, i.e. with ecology, can be seen through the collection, calculation and interpretation of mathematical data on monthly and annual family expenses for water, electricity, food, etc. Through the analysis of statistical data collected by students through work and calculation, they come to a conclusion on how to influence energy savings, reduce costs and pollution.

Phenological observation of nature, especially parameters related to environmental factors, can be realized through calendars of nature, either wall or in workbooks (Ćurčić 2018). In nature calendars, students register mathematical values of certain environmental factors every day, such as temperature, humidity, and atmospheric pressure. At the end of each month, they calculate the average values of the measured factors and make certain conclusions about the weather or climate change of a given month. Instruments for measuring individual environmental factors can be installed at the entrance to the school building or on the outside of the classroom window. Certainly a good solution is your own school meteorological station. A large number of schools in the Republic of Srpska have these measuring instruments at their disposal, by which students measure certain environmental factors.

Realizing teaching units related to traffic, students at a certain intersection (if there are conditions for that) during one school hour, divided into groups, can count how many vehicles pass through the intersection, especially cars, buses, trucks, etc. Based on mathematical analyses of the number of vehicles that passed through the intersection for a certain period of time, it is possible to indicate at least approximately the air pollution at that location, which was caused by the exhaust gases of those vehicles.

In botanical gardens, if schools have them, students in nature and society classes can count in certain seasons, not only planted herbaceous plants that are not there throughout the year, but the number of butterflies and other insects, sparrows, magpies, crows, pigeons and other birds.

According to the obtained numerical indicators, they can make a statistical analysis of the appearance of all these organisms through the seasons. They can also sort the leaves of different types of plants by shape, size and colour, different types of flowers also by shape and colour, and fruits if any, and present it all through sets that are processed as mathematical content at this level of education. 


\section{Conclusion}

Through detailed analysis of mathematics textbooks for younger grades of primary school in terms of the representation of environmental content, i.e. the frequency of mathematical tasks, and based on the descriptive method and content analysis as a research technique, and statistical data processing, we came to the realization that environmental contents, given their importance, are not sufficiently represented in the aforementioned textbooks.

Analysis of the frequency and percentage of 'environmental' tasks in mathematics textbooks by grade, indicates that the least 'environmental' tasks are in the fifth grade, and most in the first grade, although it was expected that the number of tasks that develop ecological conscience will increase in proportion to student age, i.e. by grades. Bearing in mind that out of 2668 tasks, 2560 , or $95.95 \%$, of them do not encourage environmental education and upbringing, and only 108 tasks, or $4.05 \%$, provide a greater or lesser contribution to the development of students' ecological conscience, it can be concluded that mathematics textbooks encourage environmental education and upbringing, but, in today's conditions, when it is considered an explicit task of education, they are not a sufficient contribution to building ecological conscience among students.

In this sense, the interdisciplinarity of mathematics and ecology should be the focus of future research. In order to raise students' awareness of the importance of ecology as a science, it is necessary, when creating tasks for math classes, to give more space to ecological issues and environmental issues. As students are most open to new knowledge in the period of primary school age, it is considered that this time is crucial for understanding the basic laws of nature, and developing ecological values, attitudes and behaviour in accordance with ecological principles (Mišković 2001).

\section{References}

Blagdanić, S., and M. Zeljić. 2016. 'Udžbenik kao podrška integrisanom pristupu sadržajima iz matematike i sveta oko nas.' In Naučni skup 'Nastava i učenje - udžbenik u funkciji nastave i učenja,' edited by A. Pešikan, 303-314. Užice: Učiteljski fakultet.

Ćurčić, M. 2018. Metodika nastave prirode i društva. 2 vol. Bijeljina: Univerzitet u Istočnom Sarajevu.

Ćurčić, M., C. Pašalić, D. Radivojević, and P. Mandić. 2018. Poznavanje prirode za peti razred. Istočno Novo Sarajevo: Zavod za udžbenike i nastavna sredstva.

Đikić, D., H. Glavač, V. Glavač, V. Hršak, V. Jelavić, D. Njegač, V. Simončič, O. Springer, I. Tomašković, and V. Vojvodić. 2001. Ekološki leksikon. Zagreb: Barbat. 
Đorđević, S., and D. Cvetković. 2014. Ekologija kao naučna disciplina. Beograd: Ministarstvo poljoprivrede i zaštite životne sredine, Univerzitet Singidunum, and Fondacija za ekološke akcije Green Limes.

Eulefeld, G. 1981. Ökologie und Umwelterziehung: Ein didaktisches Koncept. Sttutgart: Kohlhammer.

Jukić, R. 2011. 'Ekološko pitanje kao odgojno-obrazovna potreba.' Socijalna ekologija 20 (3): 267-286.

Maričić, S., and K. Špijunović. 2014. 'Udžbenici u funkciji razvijanja osetljivosti za probleme u nastavi matematike.' In Zbornik radova sa Naučnog skupa 'Nastava i učenje - savremeni pristupi i perspektive,' edited by R. Nikolić, 531542. Užice: Učiteljski fakultet.

Milinković, D. 2013. Metodika matematičkog modelovanja za razrednu nastavu. Pale: Filozofski fakultet.

—. 2016. 'Strukturalni elementi udžbenika matematike u funkciji razvijanja stvaralačkog mišljenja.' In Nastava i učenje - udžbenik u funkciji nastave i učenja, edited by A. Pešikan, 389-404. Užice: Učiteljski fakultet.

Mišković, M. 2001. Omladina i ekologija. Šabac: IKP 'Zaslon.'

Pašalić, S., D. Radivojević, and C. Stanojlović. 2019. Priroda i društvo za 4. razred osnovne škole. Istočno Sarajevo: Zavod za udžbenike i nastavna sredstva.

Pikula, M., and D. Milinković. 2015. Metodika početne nastave matematike. Pale: Filozofski fakultet.

Robitaille, D. F., and K. J. Travers. 1992. 'International Studies of Achievement in Mathematics.' In Handbook of Research on Mathematics Teaching and Learning: A Project of the National Council of Teachers of Mathematics, edited by D. A. Grouws, 687-709. New York: Macmillan.

Skenderović, I., and M. Fetić. 2014. 'Uloga ekološkog obrazovanja u zaštiti i unapređenju životne okoline.' Ekonomski izazovi 3 (5): 123-134.

Skenderović, I., and J. Romelić. 2013. 'Zaštita okoline u nastavnim planovima i programima osnovne škole u Republici Srbiji.' Ekonomski izazovi 2 (3): 151160.

Žderić, M. 1983. Škola i životna sredina. Novi Sad: Misao.

\section{Zastopanost ekoloških vsebin v učbenikih matematike}

Okoljska vzgoja je sestavni del sodobnega splošnega izobraževanja in je v tem smislu nepogrešljiv sestavni del načrtovanja in programiranja učnega procesa. Okoljsko izobraževanje in vzgoja kot interdisciplinarno načelo najdeta svoje mesto $v$ različnih izobraževalnih programih, $v$ naših šolah pa sta najbolj zastopana pri poučevanju integriranih naravoslovnih ved. Upoštevajoč nujnost matematičnega znanja za razumevanje pojavov in zakonov $v$ naravi ter družbi se v nižjih razredih učenci srečujejo s pojavi in problemi ekologije v vsakdanjih življenjskih razmerah tudi pri pouku matematike. Okoljske dejavnosti si sledijo skozi vsebino učbenikov, matematične zgodbe in naloge z ekološkim sporočilom ter jih srečamo $v$ pristopih reševanja matematičnih problemov, na primer 
v nalogi o zbiranju in analizi matematičnih podatkov o onesnaženosti vode, tal in zraka, velikosti zelenih površin v mestu, količini smeti ... Še posebej pomembne so praktične dejavnosti, ki se lahko nanašajo na oblikovanje ekokotička, $v$ katerem bodo učenci našli natančne matematične rešitve uporabe recikliranega materiala določenega okolja. Analiza vsebine učbenikov matematike je pokazala, da le-ti spodbujajo okoljsko izobraževanje in vzgojo, seveda pa ne zadoščajo za krepitev okoljske ozaveščenosti učencev, saj se okoljska vzgoja dandanes zahteva kot poseben predmet splošnega izobraževanja.

Ključne besede: interdisciplinarno načelo, matematika, okoljsko izobraževanje in vzgoja, učbeniki 